\title{
Eukaryotic Translation Initiation Factor 5
}

National Cancer Institute

\section{Source}

National Cancer Institute. Eukaryotic Translation Initiation Factor 5. NCI Thesaurus. Code C104662.

Eukaryotic translation initiation factor 5 (431 aa, $\sim 49 \mathrm{kDa}$ ) is encoded by the human ElF5 gene. This protein plays a role in the interaction between the $40 \mathrm{~S}$ and $60 \mathrm{~S}$ ribosomal subunits. 